\title{
Biogenesis of Zinc Oxide Nanoparticles Using Lawsonia Inermis Leafextract and Their Mosquitocidal, Antimicrobial, Anticancer, Andmoderate Toxic Side Effects on Predatory Copepods and Fish
}

\author{
Pandiyan Amuthavalli \\ Bharathiar University \\ Jiang-Shiou Hwang ( $\sim$ jshwang@mail.ntou.edu.tw) \\ National Taiwan Ocean University \\ Hans-Uwe Dahms \\ Kaohsiung Medical University \\ Lan Wang \\ Shanxi University \\ Jagannathan Anitha \\ Bharathiar University \\ Murugan Vasanthakumaran \\ Kongunadu Arts and Science College \\ Arumugam Dhanesh Gandhi \\ Thiruvalluvar University \\ Kadarkarai Murugan \\ Bharathiar University \\ Jayapal Subramaniam \\ Bharathiar University \\ Manickam Paulpandi \\ Bharathiar University \\ Balamurugan Chandramohan \\ Bharathiar University \\ Shivangi Singh \\ Kaohsiung Medical University
}

\section{Research Article}

Keywords: Zinc oxide, nanoparticle, antimicrobial, antimalaria, SEM, XRD, ecofriendly

Posted Date: December 8th, 2020

DOI: https://doi.org/10.21203/rs.3.rs-115447/v1

License: @ (i) This work is licensed under a Creative Commons Attribution 4.0 International License. Read Full License

Version of Record: A version of this preprint was published at Scientific Reports on April 23rd, 2021. See the published version at https://doi.org/10.1038/s41598-021-88164-0. 


\section{Abstract}

Background and Objectives: Microbes or parasites spread vector-borne diseases by mosquitoes without being affected themselves. Insecticides used in vector control produce a substantial problem for human health.

Materials and Methods: This study synthesized zinc oxide nanoparticles (ZnO NPs) using Lawsonia inermis L. and were characterized by UV-vis, FT-IR, SEM with EDX, and XRD analysis.

Results: Green synthesized ZnO NPs were highly toxic against Anopheles stephensi, whose lethal concentrations values ranged from 5.494 ppm (I instar), 6.801 (II), 9.336 (III), 10.736 (IV), and 12.710 ppm (pupae) in contrast to L. inermis treatment. The predation efficiency of the teleost fish Gambusia affinis and the copepod Mesocyclops aspericornis against $A$. stephensi was not affected by exposure at sublethal doses of ZnO NPs. The predatory potency for $G$. affinis was 45 (I) and $25.83 \%$ (IV), copepod M. aspericornis was 40.66 (I) and $10.8 \%$ (IV) while in an ZnO NPs contaminated environment, the predation by the fish G. affinis was boosted to 71.33 and $34.25 \%$, and predation of the copepod M. aspericornis was 60.35 and $16.75 \%$, respectively. ZnO NPs inhibited the growth of several microbial pathogens including the bacteria (Escherichia coli and Bacillus subtilis) and the fungi (Alternaria alternate and Aspergillus flavus), respectively. ZnO NPs decreased the cell viability of Hep-G2 with $\mathrm{IC}_{50}$ value of $21.63 \mu \mathrm{g} / \mathrm{mL}\left(\mathrm{R}^{2}=0.942 ; P<0.001\right)$ while the concentration increased from 1.88 to $30 \mu \mathrm{g} / \mathrm{mL}$.

Conclusion: These outcomes support the use of L. inermis mediated ZnO NPs for mosquito control and drug development.

\section{Introduction}

Worldwide, mosquitoes (Diptera: Culicidae) are threatening human individual and public health as vectors of parasites and pathogens ${ }^{1}$. Mosquitoes provide a substantial threat when compared to other disease-transmitting insects as they spread disease causing pathogens. Anopheles stephensi is a vector which transmits the globally most threatful contagious disease malaria ${ }^{2}$. The most serious health problem caused by malaria affects 214 million cases in $2015^{3,4}$. The appearance of multi-drug resistance of the disease causing protists belonging to Plasmodium spp. possess a major obstacle to successful chemoprophylaxis and chemotherapy of this disease ${ }^{5}$.

Then exposure to acoustic vibrations within determined frequency bands leads to dorsal tracheal trunk (DDTs) wall rupture in mosquitoes, resulting in the discharge of gases into the body cavity, that block larval development, increase mortality rates or rendering adult mosquitoes flightless. Phyto-constituents that are naturally synthesized by medicinal plants can be utilized for ecofriendly applications in vector control ${ }^{6}$. Nanocomplexes using phyto- and microorganisms will minimize the side effects caused by synthetic drugs and also the toxicity to target organisms ${ }^{7}$ in an environmentally friendly manner ${ }^{8}$. Drug resistance provides the main drawback in executing chemotherapy in cancer ${ }^{9}$. The development of efficient versatile drugs against both mosquito-borne diseases and cancer were highlighted ${ }^{10}$.

In spite of increasing evidence for the outstanding mosquitocidal potency of phyto-synthesized nanocompounds and their toxicity against natural predators of mosquitoes, their effects have rarely been studied with respect to sub-lethal doses on predation ${ }^{11}$. Water predators, including juvenile instars of dragon flies, tadpoles, beetles, fishes, and crustaceans ${ }^{12}$. The impact of predatory animals on water bodies is important because such predators were introduced throughout many warm regions of the world for mosquito control ${ }^{13}$. Metabolities such as carbonyl, hydroxyl and functional groups of amines, especially the OH-group of flavonoids that react with metal ions leads to reduced size of metal ions used for nanoparticle synthesis. Zinc oxide nanoparticles can show several morphological varieties such as nanoflowers, nanosheets and even nanorods which were shown to successfully inhibit the growth and development of the bacteria Escherichia coli, Staphylococcus aureus, and Klebsiella pneumonia. Plant derived nanomaterials exhibit various shapes and sizes when compared to nanoparticles produced by other organisms such as algae, fungi, and bacteria. There is no published report that evaluates zincoxide nanocomplex toxicity against the non-target predatory efficiency of Mesocyclops aspericornis. Traditional medicine records the plant Lawsonia inermis $\mathrm{L}$. as a potential natural dye with numerous medicinal applications. Nanoparticles that are synthesized from the plant materials showed several applications in fields such as medicine, agriculture and the food industry. ZnO NPs (zinc oxide nanoparticles which exhibit remarkable properties such as binding energy (large) and band gap (wide). These were the properties which made zinc oxide nanoparticles biocompatible, safe, and non-toxic. Zinc oxide nanoparticles are known to have different applications, such as in medical and biological industries, optoelectronics, as antiplatelet agents, anti-inflammatory, anti-angiogenesis, especially as auspicious anti-cancer agents, providing catalytic and semiconductor properties. Zincoxide nanoparticles are known to show insecticidal properties. ZnO NPs were synthesized from L. inermis in the present study are also used to resolve the following issues: 
a) the lethal effect against the $A$. stephensi malaria vector, to find out the larvicidal and pupicidal effect; $b$ ) the predatory efficiency of the Gambussia affinis fishes and small crustacean Mesocyclops aspericornis against younger instars of Anopheles larvae in ZnO NPs contaminated water environments; c) antimicrobial potential of nano-formulations against pathogenic microorganism and; d) in-vitro cytotoxicity against the cancer Hep-G2 cells.

\section{Materials And Methods}

Several aspects of below M\&M are similar to and detailed by our earlier paper Jaganathana et al. $(2016)^{14}$. All methods were performed in accordance with the relevant guidelines and regulations of international law and the IAECC of Bharathiar University (see below statement).

Anopheles stephensi cultivation

Details are provided in our earlier paper Jaganathana et al. (2016) ${ }^{14}$. Anopheles stephensi eggs were collected from a local breeding habitat, a fresh water tank in Kalveerampalaiyam, Coimbatore (Tamil Nadu, India) and laboratory reared for egg hatching ( $80 \%$ relative humidity and $27^{\circ} \mathrm{C}$ and a photoperiod of $14: 10 \mathrm{~h}(\mathrm{~L} / \mathrm{D})$. Emerging larvae and pupae were used for toxicological testing as outlined below.

\section{Leaves collection and processing}

Plant sample (Lawsonia inermis) was collected in Maruthamalai hill, Coimbatore, Tamil Nadu, India). It was authenticated at the Botanical Survey of India, whose voucher specimens number was BSI/SRC/5/23/2019/Tech and deposited at the Department Zoology, Bharathiar University. The leaves were rinsed by tap water and dried at room temperature $\left(28 \pm 2{ }^{\circ} \mathrm{C}\right)$, and finely powdered. Powdered leave material $(10 \mathrm{~g})$ were boiled with $100 \mathrm{~mL}$ of double distilled water for further nanocomposite preparation.

\section{Synthesis of ZnO NPs}

The leaf broth was combined with $1-\mathrm{mM} \mathrm{ZnNO}_{3}$ (Sigma-Aldrich, India) solution and was stirred at room temperature $\left(35 \pm 2{ }^{\circ} \mathrm{C}\right)$ for $1 \mathrm{~h}$. A brown-yellowish precipitate was heated under stirring at $60^{\circ} \mathrm{C}$ for $4 \mathrm{~h}$ and further, the solution was continuously stirred at room temperature for $24 \mathrm{~h}$. The precipitate was dried at $100^{\circ} \mathrm{C}$. The obtained sample was ground gently using a pestle and mortar and finally, the sample was calcined at $400{ }^{\circ} \mathrm{C}$ for $3 \mathrm{~h}$.

\section{Characterization}

The synthesized ZnO NPs samples were analyzed by a UV-vis diffuse reflectance spectroscopy (UV-vis DRS) at a wavelength range of 200-700 nm, using a UV-vis spectrophotometer (Shimadzu - UV 2600, Tokyo, Japan). Fourier transform infrared spectroscopy (FT-IR) analysis was carried out using a spectrum 65 FT-IR spectrometer (PerkinElmer Co., Ltd., Massachusetts, USA). ZnO NPs were used for scanning electron microscopy (FEI QUANTA-200; SEM), energy-dispersive X-ray spectroscopy (EDX) ${ }^{15}$. XRD pattern were recorded using Cu Ka radiation at a wavelength of $1.54060 \AA$, with a nickel monochromator in the $2 \theta$ range from 10 to $80^{\circ}$ using an analytical X-PERT PRO, diffractometer.

Acute toxicity assessment against $\mathrm{A}$. stephensi

In the laboratory the larvae and pupae of $A$. stephensi (I, II, III, or IV instars) were exposed for $24 \mathrm{~h}$ at concentrations of 20, 40, 60, 80 and $100 \mathrm{ppm}$ of $L$. inermis broth and 2, 4, 6, 8 and $10 \mathrm{ppm}$ of ZnO NPs in triplicates. Dechlorinated water without acetone served as a control. Using probit analysis (Finney, 1971) $\mathrm{LC}_{50}$ and $\mathrm{LC}_{90}$ were calculated as follows (Eq. 1):

Percent mortality $=($ number of dead individuals/ number of treated individuals) $\times 100$ (Eq. 1$)$

Biotoxicity assay on Gambusia affinis

Details are provided in our earlier paper Jaganathana et al. (2016) ${ }^{14}$. Teleost fishes of Gambusia affinis were collected from the Tamil Nadu Fisheries Department (Mettur Dam, Salem, Tamil Nadu, India) and maintained at $27 \pm 3^{\circ} \mathrm{C}$ and R.H. $85 \%$ in cement tanks $(120 \mathrm{~cm}$ diameter, $60 \mathrm{~cm}$ depth) filled with field collected water.

Predation assays under standard laboratory conditions 
Details are provided in our earlier paper Jaganathana et al. (2016) ${ }^{14}$. Here, predation efficiency of $G$. affinis adults was assessed against A. stephensi (I - IV) instar larvae. In each trial mosquitoes, $n=200$ larvae were introduced with one $G$. affinis adult in a 2-L glass arena filled with dechlorinated water and five replicates were conducted. Control arenas contained dechlorinated water only. All arenas were checked every $24 \mathrm{~h}$ for 5 days and the number of prey missing that were assumed to be eaten by mosquito fish was recorded. After each check, the missing mosquito larvae were replaced with new ones. Predation efficiency was calculated by (Eq. 2). Predation efficiency = (Number of consumed mosquitoes/ total number of mosquitoes) $\times 100$ (Eq. 2). We confirm that the experimental protocol was approved by the here named institutional committee: Institutional Animal Ethical Clearance Certificate (IAEC) of the Bharathiar University, Coimbatore - 641046 (see appended original document signed by IAEC Chairman Prof. V. Vijaya Padma).

Predatory efficiency of G. affinis species after treatment with synthesized ZnO NPs

Details are provided in our earlier paper Jaganathana et al. (2016) ${ }^{14}$. Predation assays in contaminated aquatic environments: the predation efficiency of $G$. affinis adults was assessed against I-IV instar larvae of $A$. stephensi, after a mosquitocidal treatment with standard and green-synthesized ZnO NPs. For both mosquitoe species, $n=200 \mathrm{IIV}$ instar larvae were introduced with one $G$. affinis adult in a $2 \mathrm{~L}$ glass tank filled with dechlorinated water plus $1 \mathrm{~mL}$ of the desired concentration of NPs (i.e. $5 \mathrm{ppm}$ of ZnO NPs, $1 / 3$ of the LC 50 calculated against I instar mosquito larvae $)^{16}$. For each mosquito species, three replicates were used. Control was dechlorinated water only. All experimental tanks were checked every $24 \mathrm{~h}$ at day and night time and the number of prey eaten by mosquito fishes was recorded. After each checking, the predated mosquito larvae were replaced by new ones. Predation efficiency was calculated using the above-mentioned formula (Eq. 2).

Predation of Mesocyclops aspericornis against malaria mosquitoes

Details are provided in our earlier paper Jaganathana et al. (2016) ${ }^{14}$. In this experiment, the predation efficiency of Mesocyclops aspericornis adults was assessed against $A$. stephensi larvae. For each instar, $n=100$ mosquitoes were introduced, with 10 copepods, in a $500-\mathrm{mL}$ glass beaker containing $250 \mathrm{~mL}$ of dechlorinated water. Mosquito larvae were replaced daily by new ones. For each mosquito instar, five replicates were conducted. Control was $250 \mathrm{~mL}$ of dechlorinated water without copepods. All beakers were checked after 1, 2, 3,4 and 5 days and the number of prey consumed by copepods was recorded. Predatory efficiency was calculated using the following formula (Eq. 2):

Predation efficiency $=$ (Number of consumed mosquitoes/ total number of mosquitoes $) \times 100$

Predation of M. aspericornis against malaria mosquitoe post-treatment with ZnO NPs

Here, we evaluated the predation efficiency of $M$. aspericornis adults against $A$. stephensi larvae, after a mosquitocidal treatment with synthesized ZnO NPs. For each instar, $n=100$ mosquitoes were introduced with 10 copepods in a 500 -mL glass beaker filled with dechlorinated water treated with synthesized ZnO NPs (i.e. for both species, 1/3 of the $\mathrm{LC}_{50}$ calculated against first instar larvae). Mosquito larvae were replaced daily with new ones. For each mosquito instar, five replicates were conducted. Consumed by copepods was recorded. Predatory efficiency was calculated using the above-mentioned formula (Eq. 2). Control was dechlorinated water without copepods. All beakers were checked after 1,2,3,4 and 5 days and the number of prey consumed by copepods was recorded.

\section{Antimicrobial inhibitory assay}

All were provided by the Microbial Type Culture Collection and Gene Bank Institute of Microbial Technology Sector 39-A, Chandigarh160,036 (India). Antimicrobial activity of Li-ZnO NPs was tested against the selected bacteria (Escherichia coli and Bacillus subtilus) and the fungal strains (Alternaria alternate and Aspergillus flavus) using the disk diffusion method ${ }^{17,18}$. The standard inoculum suspension $\left(10^{6} \mathrm{CFU} / \mathrm{ml}\right)$ was streaked over the surface of the media using a sterile cotton swab to ensure confluent growth of the organisms. $10 \mu \mathrm{L}$ of synthesized ZnO NPs was diluted with two volumes of $5 \%$ dimethyl sulfoxide (DMSO), impregnated on filter paper disks that were placed on the surface of the agar plates. Petri plates were kept for incubation at room temperature $\left(27^{\circ} \mathrm{C} \pm 2\right)$ for $24 \mathrm{~h}$. Inhibition was measured in millimeters using a photomicroscope (Leica ES2, Leipzig, Germany) and compared with standard positive controls, i.e. tetracycline (for bacteria) and fluconazole (for fungi).

\section{Cytotoxicity on liver cancer cell lines}

Human liver cancer cell line (Hep-G2) was obtained from National Centre for Cell Science (NCCS), Pune and grown in Eagles Minimum Essential Medium containing 10\% fetal bovine serum (FBS). The cell lines were cultured and incubated according to the procedure given and used for further toxicity studies.

Page $4 / 18$ 


\section{MTT assay}

After $48 \mathrm{~h}$ of incubation, $15 \mu \mathrm{L}$ of MTT $\left(5 \mathrm{mg} / \mathrm{mL}\right.$ ) in phosphate buffered saline (PBS) was added to each well and incubated at $37^{\circ} \mathrm{C}$ for $4 \mathrm{~h}$. The medium with MTT was then flicked off and the formed formazan crystals were solubilized in $100 \mu \mathrm{L}$ of DMSO and then measured at $570 \mathrm{~nm}$ using a microplate reader. Following the below mentioned formula the cell viability will be calculated (Eq. 3)

Percentage Cell Viability $(\%)=($ Mean experimental call absorbance $($ A620) $/($ Mean

control call absorbance (A620)) $\times 100$ (Eq. 3)

\section{Data analysis}

SPSS 16.0 version was used for all analyses. The average larval and pupal mortality data were subjected to probit analysis for calculating $\mathrm{LC}_{50}, \mathrm{LC}_{90}$, and other statistics at $95 \%$ confidence limits, and chi-square values were calculated using the SPSS Statistical software package 13.0 version. Results with $P<0.05$ were considered as statistically significant.

\section{Results}

As shown in Fig. 1, the absorption spectra obtained for biosynthesized ZnONP were at $364 \mathrm{~nm}$ when investigated under UV-spectroscopy. This absorption was confirmed by the formation ZnO NPs. When L. inermis extract was analyzed by FTIR, its spectrum showed several vibration peaks at $3575,3272,2073,1636$ and $489 \mathrm{~cm}^{-1}$. Thereafter, synthesized ZnO NPs spectrum showed vibration peaks at 1473 , 878,668 , and $575 \mathrm{~cm}^{-1}$ (Fig. 2). The nanostructure of synthesized ZnO NPs was seen in SEM which acquired $5 \mathrm{~nm}$ given in Fig. 3. EDX analysis of synthesized ZnO NPs showed dual peaks which were situated between 1.2 and $8.6 \mathrm{keV}$, where it is for zinc characteristic lines $K$ and $L$ shell, as shown in Fig. 4. XRD analysis of synthesized zinc oxide nanoparticles showed intense spectra at $2 \theta=31.76,34.42$, $36.24,47.53,56.59,62.86,66.38,67.94,69.08,72.56,76.92^{\circ}$ parallel to $100,002,101,102,110,103,200,112,201,004$, and 202 planes, in that order as shown in Fig. 5. Table 1 predicts the mortality of young instar and pupae of malarial vector (I - IV young ones) when exposed to $L$. inermis at the concentrations of 20, 40,60, 80, and $100 \mathrm{ppm}$ with the following LC $\mathrm{C}_{50}$ values: 73.439 (I), 95.204 (II), 110.731 (III), 123.173 (IV), and $131.816 \%$ (pupae). Similarly, Table 2 shows the toxicity against larva and pupa of synthesized ZnO NPs. The toxicity was found to be higher at doses of 2, 4, 6, 8 and 10 ppm whose LC $_{50}$ were found to be 5.494 (I), 6.801 (II), 9.336 (III), 10.736 (IV), and $12.710 \%$ (pupae).

Food feeding competence of $G$. affinis fishes were calculated, against I to IV instar larvae of $A$. stephensi. Very small doses of synthesized ZnO NPs were treated with water under standard laboratory conditions where the fishes were introduced, their predation rate subsequent after $24 \mathrm{~h}$ was $45 \%$ (I) to 25.83 (IV). The food utilization of $G$. affinis was 71.33 (I) to $34.25 \%$ (IV), respectively (Table 3). $M$. aspericornis adults predate on $A$. stephensi young larval instars. The predatory efficiency per copepod per day was 4.06, 2.87, 1.79 and 1.08 larvae (I, II, III, and IV, respectively). During post-treatment with sub-lethal doses of synthesized ZnO NPs, the predation efficiency was boosted to 4.06, 2.87, 1.79 and 1.67 larvae (I, II, III, and IV, respectively) (Table 4).

Antimicrobial effects of synthesized ZnO NPs against selected pathogens like $E$. coli and B. subtilis (bacteria) and fungal species like Alternaria alternate, and Aspergillus flavus were evaluated in the present investigation. Synthesized ZnO NPs were highly effective in inhibiting the growth of $E$. coli $(13.3 \mathrm{~mm})$ which were then followed by $B$. subtilus $(8.4 \mathrm{~mm})$ respectively given in Table 5 and Fig. 6. Similarly, a maximum zone of inhibition was achieved for the fungus Alternaria alternate $(11.5 \mathrm{~mm})$, followed by Aspergillus flavus (7.8 $\mathrm{mm}$ ). Synthesized ZnO NPs treated with Hep-G2 cell lines were tested to ensure its cell viability after $24 \mathrm{~h}$. The cytotoxicity on Hep-G2 cell lines mediated by ZnO NPs exhibited a dose-dependent relationship as shown in Fig. 7. Here, $\mathrm{IC}_{50}$ values were found to be $21.63 \mu \mathrm{g} / \mathrm{mL}$ $\left(R^{2}=0.942 ; P<0.001\right)$, respectively, and its morphology and cell inhibition was shown in Fig. 8.

\section{Discussion}

As shown in Fig. 1, a UV-vis DRS analysis of synthesized ZnO NPs showed an absorption peak at $364 \mathrm{~nm}$, revealing a blue shift at a band gap value of $3.40 \mathrm{eV}$. The direct band gap of the synthesized ZnO NRs was evaluated using Eq. (4); $\mathrm{Eg}=1240 / \lambda_{\max }$ Eq. (4), where Eg provides the band gap $(\mathrm{eV})$ and $\lambda_{\max }$ is the wavelength $(\mathrm{nm})$ of the absorption edge within the spectrum. As a red shift indicates an increase in particle size and a blue shift indicates a decrease in particle size. Generally, green synthesized ZnO NPs show an absorption peak at $375 \mathrm{~nm}$ and a band gap at $3.30 \mathrm{eV}$. The higher band gap ZnO NPs was suitable for biological application, which highly promoted 
the generation of ROS in NPs. In this study, synthesized ZnO NPs exhibited a blue shift of an absorption peak at 364 nm higher ban gap value at $3.31 \mathrm{eV}$. The same trend was observed with previous reports ${ }^{19,20,21}$.

FT-IR spectrum of $L$. inermis extract exhibited various stretching and transmittance peaks corresponding to various functional groups including alkyl halides, amine, alkynes, and alcohols. Here, peptide bonds of proteins correspond to $\mathrm{N}-\mathrm{H}$ and $\mathrm{C}=\mathrm{O}$ stretching frequencies exhibiting a peak at $3575 \mathrm{~cm}^{-1}$. A similar banding pattern at $3402 \mathrm{~cm}^{-1}$ was reported by Natarajan et al. 22 and or alcohols and/or phenols, as well as aliphatic amines support the presence of polyphenols at $1027 \sim 1092 \mathrm{~cm}^{-1}$ for $\mathrm{C}-\mathrm{N}$ vibration ${ }^{23}$. The peaks at $802 \mathrm{~cm}^{-1}$, stay for the $\mathrm{C}-\mathrm{H}$ stretching frequencies within the free catechins in the aromatic ring ${ }^{24}$. The plant extract consists of bioactive molecules which help in the nucleation process and the formation of $\mathrm{Zn}(\mathrm{OH})_{2}$. After calcining at $400^{\circ} \mathrm{C}$, the sample changed from $\mathrm{Zn}$ $(\mathrm{OH})_{2}$ into ZnO NPs. The synthesized ZnO NPs spectrum reveal several characteristic peaks at 1473, 878, and $668 \& 575 \mathrm{~cm}^{-1}$ respectively, being similar in the vibration modes of the functional chemical bonds of $\mathrm{C}=\mathrm{O}$ symmetric stretching, $\mathrm{C}-\mathrm{H}$ bending, and weak Zn-O stretching. Evaluating the surface morphology of synthesized ZnO NPs, our results indicate them as spherical structures of an average of $5 \mathrm{~nm}$ in size. Typically, the green synthesized ZnO NPs using phytoconstituents and its products attain morphologies like cubic, rod, triangular, spherical, or sometimes they are flat round of sizes ranging between 5 to $35 \mathrm{~nm}^{25}$. Different size and shape of ZnO NPs was related to plant species and bioactive compounds ${ }^{26,27}$. EDX spectra indicates 0 and $\mathrm{Zn}$ elements having energy levels of 0.5 , 1.2, and $8.6 \mathrm{keV}$, respectively. Moreover, two additional peaks of $\mathrm{Cl}$ and $\mathrm{Ag}$ were found as well. The major peak of the sample represented $\mathrm{Ag}$, which was due to the sputter coating process with silver (Ag). XRD analysis of synthesized ZnO NPs demonstrated a well-crystallized structure. The three distinctly high diffraction peaks at $2 \theta=31.75,34.40$, and $36.25^{\circ}$ corresponded to the planes of (100), (002), and $(101)^{28,29,30}$. This was confirmed by the hexagonal structure of ZnO. This was also matching well with the JCPDS card no. 36-1451.

The toxicity on larval and pupal stages of $A$. stephensi caused by ZnO NPs might be due to the reduction of nanoparticles caused by the plant extract. The tiny NP spheres penetrate cells and interfere with physiological processes such as molting ${ }^{31}$. The present study corroborates with the findings of Gandhi and Madhusudhan ${ }^{32}$, who postulated the efficiency of Momordica charantia leafes reducing ZnO NPs against $C$. quinquefasciatus and $A$. stephensi. Murugan et al. ${ }^{33}$ found that Sargassum wightii-synthesized ZnO NPs were highly effective in killing the larvae and pupae of the malaria vector $A$. stephensi. In contrast, silver nanoparticles were found to be efficient at lower doses against the malarial vector $A$. stephensi- however, only against its young instars. Equally high toxic effects against larvae and pupae of $A$. stephensi. were provided by leaf extracts from both $S$. occidentalis and Ocimum basilicum. A dose dependent effect was in agreement with previous evidences from other plant extracts ${ }^{34}$. Our results clearly indicate that ZnO NPs affect pathogen growth by cell wall disruption. ZnO NPs may reduce surface hydrophobicity of bacterial cells and its oxidative stress-resistance genes were downregulated, causing finally degradation and the death of cells ${ }^{35}$. ZnO NPs has freshly achieved individual notices concerning possible electronic applications due to its unique optical, electrical, and chemical properties ${ }^{36}$. Its heterogeneous catalytic property might be the cause for bacterial growth inhibition through different mechanisms as known from conventional antibiotics ${ }^{\mathbf{3 7}, 38}$. Previous reports of 7074 postulates higher MIC of ZnO NPs against E. coli, Listeria monocytogenes, Salmonella typhi, and $S$. aureus provide supportive evidence for the present microbial evaluation. Most of the fungal strains like F. solani, $A$. alternate, and $A$. flavus had shown antifungal drug resistance ${ }^{39}$. Hence it was in need to formulate nanoparticles with potent chemical and structural nature to overcome such drug resistance ${ }^{40}$.

Similarly, Chobu et al. ${ }^{41}$ demonstrated that Anopheles gambiae was less efficiently predated upon by the mosquitofish $G$. affinis. Murugan et al. ${ }^{\mathbf{4 2}}$ noted that the teleost guppy fish, $P$. reticulata actively predates on the larvae of $A$. stephensi. Subramaniam et al. ${ }^{\mathbf{3}}$ mentioned another study showing that green synthesized Ag NPs with Mimusops elengi did not affect predation rates of the mosquitofish $G$. affinis on the mosquitoes $A$. albopictus and $A$. stephensi. In a paper by Murugan et al. ${ }^{44}$ the predatory efficiency of a single copepod species belonging to $M$. aspericornis was 8.0, 6.3, 0.8, and 0.2 larvae (instar I, II, III, and IV, respectively) per day after a post-treatment with seaweed-synthesized silver nanoparticles. Mahesh Kumar et al. ${ }^{45}$ studied the predatory efficiency of a single adult copepod of $M$. thermocyclopoides being 6.5, 4.6, 0.76, and 0.14 C. quinquefasciatus larvae per day (instar I, II, III, and IV, respectively). The predatory efficiency was enhanced to 8.7, 5.9, 1.2, and 0.36 larvae day (instar I, II, III, and IV, respectively) after treatment with Solanum xanthocarpum fruit extract.

ZnO NPs acted as anticancer agents with minimum dosage as confirmed by the $\mathrm{IC}_{50}$ values. Silver nanoparticles and earthworm combinations mediated anti-proliferative activity at increasing concentration as revealed by DNA analysis of Hep-G2 cells ${ }^{18}$. Similarly ${ }^{46}$, Amorphophallus paeoniifolius peels mediated ZnO NPs induced cancer cell apoptosis at increasing concentration also in accordance with our present findings. 


\section{Conclusion}

The emergence of multi-drug resistance of vectors and microbes provide a major obstacle for the successful control of mosquitoes, as well as chemoprophylaxis and chemotherapy of diseases. Hence, there is an urgent need to develop a novel, rapid synthesis, and ecofriendly tool in mosquito control. Physicochemically characterized ZnO NPs reduced by leaves of Lawsonia inermis were shown to have multipotency against of $A$. stephensi larvae and pupae, Hep-G2 cancer cell lines, and selected pathogens including bacteria and fungi. Green synthesis of ZnO NPs provides a potential candidate in controlling young instars of blood feeding malaria vectors, inducing apoptosis in a dose-dependent manner, and inhibiting microbial growth. Therefore, this was an effective regularized and eco-friendly approach that can be used as one of the ways to decrease pathogenic microbial and mosquito populations.

\section{Declarations}

\section{DECLARATION OF COMPETING INTEREST}

The Authors declare no conflict of interest.

\section{ACKNOWLEDGMENTS}

Dr. J. Anitha is grateful to the University Grant Commission (New Delhi, India), Project No. PDFSS-2014-15-SC-TAM-10125.

\section{References}

1. Benelli, G. Green synthesized nanoparticles in the fight against mosquito-borne diseases and cancer - a brief review. Enzyme Microbial Technol, 95: 58-68 (2016).

2. Dash, A.P., Valecha, N. \& Anvikar, A. R. Malaria in India: Challenges and opportunities. J. Biosci, 33(4): 583-928 (2008).

3. World Malaria Report: Geneva: World Health Organization. Accessed on $18^{\text {th }}$ July 2017.

4. Olotu, A., Fegan, G., Wambua, J., Nyangweso, G. \& Leach, A. et al., Seven-year efficacy of RTS, S/AS01 malaria vaccine among young African children. N. Engl. J. Med, 374: 2519-29 (2016).

5. Solomona, S., Plattnerb, G. K., Knuttic, R. \& Friedlingsteind, P. Irreversible climate change due to carbon dioxide emissions. Proc. Natl. Acad. Sci. USA., 106: 1704-1709 (2009).

6. Shaalan, E. A. S., Canyonb, D., Younesc, M. W. F., Abdel-Wahaba, H. \& Mansoura, A. H. A review of botanical phytochemicals with mosquitocidal potential. Int, 3: 1149-66 (2005).

7. Soni, N. \& Prakash, Green nanoparticles for mosquito control, Scientific World Journal, 6. Article ID 496362 (2014).

8. Abinaya, M., Vaseeharan, B., Divya, M., Vijayakumar, S. \& Govindarajan, M. et al., Structural characterization of Bacillus licheniformis Dahb1 exopolysaccharide antimicrobial potential and larvicidal activity on malaria and Zika virus mosquito vectors. Environ. Sci. Pollut. Res, 25, 5 (2018).

9. Shawkey, A. M., Rabeh, M. A., Abdulall, A. K. \& Abdellatif, A. O. Green nanotechnology: anticancer activity of silver nanoparticles using Citrullus colocynthis aqueous extracts. Adv. Life Sci. Tech, 13: 60-70 (2013).

10. Thomas, S., Ravishankaran, S. \& Johnson Amala Justin, N. A. Resting and feeding preferences of Anopheles stephensi in an urban setting, perennial for malaria. Malar. J., 16(11): 1-7 (2017).

11. Murugan, K., Roni, M., Panneerselvam, Aziz, C. A. T. \& Suresh, U. et al., Sargassum wighti-synthesized ZnO nanoparticles reduce the fitness and reproduction of the malaria vector Anopheles stephensi and cotton bollworm Helicoverpa armigera. Physiological and Molecular Plant Pathology, 101: $202 \mathrm{e} 213$ (2018).

12. Kalimuthu, K., Panneerselvam, C., Murugan, K. \& Hwang, J. S. Green synthesis of silver nanoparticles using Cadaba indica Lam leaf extract and its larvicidal and pupicidal activity against Anopheles stephensi and Culex quinquefasciatus. Entomol. Acarol. Res., 45(2): e11 (2013).

13. Patra, A., Raja, A. S. M. \& Shah, N. Current developments in (Malaria) mosquito protective methods: A review paper, Int. J. Mosquito Res., 6(1): 38-45 (2019).

14. Jaganathana, A., Murugan, K., Panneerselvam, C. et al. (+16), Earthworm-mediated synthesis of silver nanoparticles: A potent toolagainst hepatocellular carcinoma, Plasmodium falciparum parasites and malaria mosquitoes. Parasitology International 65 , (2016) 276-284 (2016). 
15. Ishwarya, R., Vaseeharan, B., Kalyani, S., Banumathi, B. \& Govindarajan, M. et al., Facile green synthesis of zinc oxide nanoparticles using Ulva lactuca seaweed extract and evaluation of their photocatalytic, antibiofilm and insecticidal activity. J. Photochem. Photobiol. 2018; 178: 249-258 (2018).

16. Murugan, K., Raman, C., Panneerselvam, C., Madhiyazhagan, P. \& Subramanium et al., Nano-Insecticides for the Control of Human and Crop Pests. In: C. Raman, M. Goldsmith, T. Agunbiade. (eds) Short views on insect genomics and proteomics. Entomology in focus, Springer, 4: 229-251 (2016).

17. Bauer, A. W., Kirby, W. M., Sherris, J. C. \& Turck, M. Antibiotic susceptibility testing by a standardized single disk method. Am. J. Clin. Pathol., 45(4): 493-496 (1966).

18. Anitha, J., Murugan, K., Panneerselvam, C., Madhiyazhagan, \& Dinesh, D. et al., Earthworm-mediated synthesis of silver nanoparticles: A potent tool against hepatocellular carcinoma, Plasmodium falciparum parasites and malaria mosquitoes. Parasitol. Int., 65: 276-284 (2016).

19. Ashley, E. A., Dhorda, M., Fairhurst, R. M., Amaratunga, C. \& Lim, P. et al., Spread of artemisinin resistance in Plasmodium falciparum N. Engl. J. Med., 371: 411-23 (2014).

20. Rajan, R., Chandran, K., Harper, S. L., Yun, S. I., \& Kalaichelvan, P. T. Plant extract synthesized nanoparticles: an ongoing source of novel biocompatible materials. Ind. Crop Prod. 70: 356-373 (2015).

21. Suresh, U., Murugan, K., Benelli, G., Nicoletti, M. \& Barnard, D. R. et al., Tackling the growing threat of dengue: Phyllanthus nirurimediated synthesis of silver nanoparticles and their mosquitocidal properties against the dengue vector Aedes aegypti (Diptera: Culicidae). Parasitol. Res., 114: 1551-1562 (2015).

22. Natarajan, K., Selvaraj, S. \& Murty, V. R. Microbial production of silver nanoparticle. Digest J. Nanomat. Biostruct., 5: 135-140 (2010).

23. Song, Y. J., Jang, H. K. \& Kim, S. B. Biological synthesis of gold nanoparticles using Magnolia kobus and Diopyros kaki leaf extract. Process Biochem., 44: 1133-1138 (2009).

24. Krishnan, R. \& Maru, G. B. Isolation and analysis of polymeric polyphenol fractions from black tea. Food Chem., 94: $331-340$ (2006).

25. Shankar, S., Rai, A., Ahmad, A. \& Sastry, M. Rapid synthesis of Au, Ag and bimetallic Au core-Ag shell nanoparticles using Neem (Azadirachta indica) leaf broth, J. Colloid Interface Sci., 275: 496-50 (2004).

26. Chandran, S. P., Chaudhary, M., Pasricha, R, Ahmad, A. \& Sastry, M. Synthesis of gold nanotriangles and silver nanoparticles using Aloe vera plant extract. Biotechnol. Prog., 22: 577-583 (2006).

27. Benelli, G. Plant-synthesized nanoparticles: an eco-friendly tool against mosquito vectors? Springer International Publishing Switzerland, H. Mehlhorn (ed.), Nanoparticles in the Fight Against Parasites. Parasitology Research Monographs. 8: 155-172 (2015).

28. Sadraei, R. A Simple Method for Preparation of Nano-sized ZnO. Res. Rev. J. Chem., 5(2): $45-49$ (2016).

29. Priyadarshini, K. A., Murugan, K., Panneerselvam, C., Ponarulselvam, S. \& Hwang, J. S. et al., Biolarvicidal and pupicidal potential of silver nanoparticles synthesized using Euphorbia hirta against Anopheles stephensi Liston (Diptera: Culicidae). Parasitol. Res., 111(3): 997-1006 (2012).

30. Satheeshkumar, K. \& Kathireswari, P. Biological synthesis of Silver nanoparticles (Ag-NPS) by Lawsonia inermis (Henna) plant aqueous extract and its antimicrobial activity against human pathogens. Int. J. Curr. Microbiol. Appl. Sci., 5: $926-937$ (2016).

31. Nareshkumar, G., Thomson, D., Nouf-Allehiani, M., Bruckbauer, J. \& Edwards, P.R. et al., Electron channeling contrast imaging for IIInitride thin film structures, Mat. Sci. Semicon. Proc. 2016; 47: 44-50 (2016).

32. Gandhi, S. \& Madhusudhan, N. Retrieval of Exoplanet Emission Spectra with HyDRA. 1-20 (2017).

33. Murugan, K., Aarthi, N., Kovendan, K., Panneerselvam, C. \& Chandramohan, B. et al., Mosquitocidal and antiplasmodial activity of Senna occidentalis (Cassiae) and Ocimum basilicum (Lamiaceae) from Maruthamalai hills against Anopheles stephensi and Plasmodium falciparum. Res., 114: 3657-3664 (2015).

34. Dinesh, D., Murugan, K., Madhiyazhagan, P., Panneerselvam, C. \& Nicoletti, M. et al., Mosquitocidal and antibacterial activity of greensynthesized silver nanoparticles from Aloe vera extracts: towards an effective tool against the malaria vector Anopheles stephensi? Res. 114: 1519-29 (2015).

35. Pati, F., Jang, J., Dong-Heon, H., Won Kim, S. \& Jong-Won, R. et al., Printing three-dimensional tissue analogues with decellularized extracellular matrix bioink. Nat. Commun., 5: 3935 (2014).

36. Baxter, J. B. \& Aydil, E. S. Nanowire based dye sensitized solar cells. Appl. Phys. Lett., 86: 53114 (2005).

37. Reddy, K. M., Feris, K., Bell, J., Wingett D. G. \& Hanley, C. et al., Selective toxicity of zinc oxide nanoparticles to prokaryotic and eukaryotic systems. Phys. Lett., 90(21): 213902-3 (2007).

Page $8 / 18$ 
38. Chwalibog, A., Sawosz, E., Hotowy, A., Szeliga, J. \& Mitura, S. et al., Visualization of interaction between inorganic nano-particles and bacteria or fungi. Int. J. Nanomedicine. 2010; 5: 1085-1094 (2010).

39. Saha, S., Dhanasekaran, D., Chandraleka, S. \& Panneerselvam, C. A Synthesis, characterization and antimicrobial activity of cobalt metal complex against multi drug resistant bacterial and fungal pathogen Facta universitatis Series Phys. Chem. Technol., 7 (1): 73-80 (2009).

40. Vivek, M., Kumar, P. S., Steffi, S. \& Sudha, S. Biogenic silver nanoparticles by Gelidiella acerosa extract and their antifungal effects Avicenna. J. Med. Biotechnol., 3(3): 143 (2011).

41. Chobu, Nkwengulila, G., Mahande, A. M., Mwang onde, B. J. \& Kweka, E. J. Direct and indirect effect of predators on Anopheles gambiae sensu stricto. Acta Trop., 142: 131-137 (2015).

42. Murugan, K., Dinesh, D., Kavithaa, K., Paulpandi, M. \& Ponraj, T. et al., Hydrothermal synthesis of titanium dioxide nanoparticles: mosquitocidal potential and anticancer activity on human breast cancer cells (MCF-7). Parasitol. Res., 115: 1085-1096 (2016).

43. Subramaniam, J., Murugan, K., Panneerselvam, C., Kovendan, K., \& Madhiyazhagan, P. et al., Eco-friendly control of malaria and arbovirus vectors using the mosquitofish Gambusia affinis and ultra-low dosages of Mimusops elengi-synthesized silver nanoparticles: towards an integrative approach? Sci. Pollut. Res. Int., 22(24): 20067-83 (2015).

44. Murugan, K., Priyanka, V., Dinesh, D., Madhiyazhagan, P. \& Panneerselvam, C. et al., Predation by Asian bullfrog tadpoles, Hoplobatrachus tigerinus, against the dengue vector, Aedes aegypti, in an aquatic environment treated with mosquitocidal nanoparticles. Parasitol. Res., 114: 3601-3610 (2015).

45. Mahesh Kumar, P., Murugan, K., Kovendan, K., Panneerselvam, C. \& Prasanna Kumar, K. et al., Mosquitocidal activity of Solanum xanthocarpum fruit extract and copepod Mesocyclops thermocyclopoides for the control of dengue vector Aedes aegypti. Res., 111: 609-618 (2012).

46. Anitha, J., Selvakumar, R. \& Murugan, K. Chitosan capped ZnO nanoparticles with cell specific apoptosis induction through P53 activation and G2/M arrest in breast cancer cells - In vitro approaches. Int. J. Biol. Macromol., 136: 686-696 (2019).

\section{Tables}

Table 1. Larval and pupal toxicity of Lawsonia inermis against malaria vector, Anopheles stephensi.

\begin{tabular}{|c|c|c|c|c|c|}
\hline \multirow[t]{2}{*}{ Target } & \multirow[t]{2}{*}{$\mathrm{LC}_{50}\left(\mathrm{LC}_{90}\right)$} & \multicolumn{2}{|c|}{ 95\% Confidence Limit LC ${ }_{50}\left(L_{90}\right)$} & \multirow[t]{2}{*}{ Regression equation } & \multirow{2}{*}{$\begin{array}{l}x^{2} \\
(d . f .=4)\end{array}$} \\
\hline & & Lower & Upper & & \\
\hline Larva I & 73.439(209.586) & $61.579(164.207)$ & $90.861(319.918)$ & $y=0.691+0.009 x$ & 0.046 n.s \\
\hline Larva II & $95.204(251.494)$ & 78.996(188.025) & 132.702(434.667) & $y=0.781+0.008 x$ & $0.122 \mathrm{n} . \mathrm{s}$ \\
\hline Larva III & 110.731(249.795) & $92.378(190.816)$ & 153.457(403.497) & $y=1.020+0.009 x$ & 0.422 n.s \\
\hline Larva IV & $123.173(248.584)$ & 102.902(192.720) & 169.426(385.424) & $y=1.259+0.010 x$ & 1.081 n.s \\
\hline Pupa & $131.816(238.775)$ & $111.249(189.499)$ & $175.947(349.963)$ & $y=1.579+0.012 x$ & 0.792 n.s \\
\hline
\end{tabular}

No mortality was observed in the control

$\mathrm{LC}_{50}=$ lethal concentration that kills $50 \%$ of the exposed organisms

$\mathrm{LC}_{90}=$ lethal concentration that kills $90 \%$ of the exposed organisms

$\chi^{2}=$ chi-square value

d.f. = degrees of freedom

n.s. $=$ not significant $(a=0.05)$ 
Table 2. Larval and Pupal toxicity effect of ZnO NPs synthesized using Lawsonia inermis against the malarial vector Anopheles stephensi.

\begin{tabular}{|c|c|c|c|c|c|}
\hline \multirow[t]{2}{*}{ Target } & \multirow[t]{2}{*}{$\mathrm{LC}_{50}\left(\mathrm{LC}_{90}\right)$} & \multicolumn{2}{|c|}{ 95\% Confidence Limit LC 50 (LC 90} & \multirow[t]{2}{*}{ Regression equation } & \multirow{2}{*}{$\begin{array}{l}x^{2} \\
(\text { d.f. }=4)\end{array}$} \\
\hline & & Lower & Upper & & \\
\hline Larva I & $5.494(16.661)$ & $4.371(13.761)$ & $6.487(22.547)$ & $y=0.630+0.115 x$ & 0.306 n.s \\
\hline Larva II & $6.801(18.506)$ & $5.774(15.055)$ & $8.062(25.809)$ & $y=0.745+0.109 x$ & 0.904 n.s \\
\hline Larva III & $9.336(23.442)$ & 7.877(18.025) & $12.356(37.361)$ & $y=0.848+0.091 x$ & 0.192 n.s \\
\hline Larva IV & $10.736(23.761)$ & $9.070(18.479)$ & 14.335(36.609) & $y=1.056+0.098 x$ & 0.189 n.s \\
\hline Pupa & $12.710(25.022)$ & $10.598(19.416)$ & $17.547(38.700)$ & $y=1.323+0.104 x$ & 0.905 n.s \\
\hline
\end{tabular}

No mortality was observed in the control

$\mathrm{LC}_{50}=$ lethal concentration that kills $50 \%$ of the exposed organisms

$\mathrm{LC}_{90}=$ lethal concentration that kills $90 \%$ of the exposed organisms

$\chi^{2}=$ chi-square value

d.f. $=$ degrees of freedom

n.s. $=$ not significant $(a=0.05)$

Table 3. Predation efficiency of Gambusia affinis on An. stephensi larvae in standard conditions and post-treatment of ZnO NPs.

\begin{tabular}{|llllll|}
\hline Treatment & Prey & $\begin{array}{l}\text { Daylight } \\
(\mathbf{0 - 1 2} \mathbf{~})\end{array}$ & $\begin{array}{l}\text { Night time } \\
(\mathbf{1 2 - 2 4} \mathbf{~})\end{array}$ & $\begin{array}{l}\text { Total Predation } \\
(\mathbf{n})\end{array}$ & Total Predation (\%) \\
\hline Standard conditions & I instar & $92.66 \pm 2.51$ & $88.33 \pm 1.52$ & 180.99 & 45.00 \\
\cline { 2 - 7 } & II instar & $81.66 \pm 2.08$ & $72.66 \pm 2.08$ & 154.32 & 38.58 \\
\cline { 2 - 6 } & III instar & $76.33 \pm 1.52$ & $54.00 \pm 2.00$ & 130.33 & 32.58 \\
\cline { 2 - 6 } & IV instar & $59.33 \pm 2.51$ & $44.00 \pm 2.64$ & 103.33 & 25.83 \\
\hline Post-treatment with Zn-NPs & I instar & $155.00 \pm 2.64$ & $130.33 \pm 2.51$ & 285.33 & 71.33 \\
\cline { 2 - 6 } & II instar & $126.00 \pm 2.64$ & $107.33 \pm 2.30$ & 233.33 & 58.33 \\
\cline { 2 - 6 } & III instar & $92.66 \pm 3.21$ & $79.66 \pm 1.52$ & 172.32 & 43.08 \\
\cline { 2 - 5 } & IV instar & $73.00 \pm 3.00$ & $64.00 \pm 2.00$ & 137.00 & 34.25 \\
\hline
\end{tabular}

Predation rates are means \pm SD of 3 replicates (1 fish vs. 400 mosquitoes per replicate).

Control was clean water without $G$. affinis fishes.

Within the column, means followed by the same letter are not significantly different (weighted generalized linear model, $P<0.05$ )

Table 4. Predation efficiency of Mesocyclops aspericornis on An. stephensi larvae in standard conditions and post-treatment of ZnO NPs. 


\begin{tabular}{|c|c|c|c|c|c|c|c|c|c|}
\hline \multirow[t]{3}{*}{ Treatment } & \multirow[t]{3}{*}{ Targets } & \multicolumn{6}{|c|}{ Number of consumed preys } & \multirow{3}{*}{$\begin{array}{l}\text { Total } \\
\text { Predation }\end{array}$} & \multirow{3}{*}{$\begin{array}{l}\text { Consumed } \\
\text { preys per } \\
\text { copepod } \\
\text { per day }(n)\end{array}$} \\
\hline & & & Day 1 & Day 2 & Day 3 & Day 4 & Day 5 & & \\
\hline & & \multicolumn{6}{|c|}{ Control } & & \\
\hline \multirow{4}{*}{$\begin{array}{l}\text { Standard } \\
\text { conditions }\end{array}$} & 1 & 0 & $60.25 \pm 1.89$ & $50.00 \pm 2.16$ & $38.00 \pm 2.16$ & $32.00 \pm 2.16$ & $23.00 \pm 1.63$ & 203.25 & 4.06 \\
\hline & $\|$ & 0 & $41.50 \pm 1.29$ & $36.00 \pm 1.15$ & $28.25 \pm 0.80$ & $22.25 \pm 1.70$ & $15.50 \pm 1.29$ & 143.50 & 2.87 \\
\hline & III & 0 & $26.00 \pm 0.81$ & $20.5 \pm 0.57$ & $16.50 \pm 1.29$ & $14.25 \pm 1.70$ & $12.50 \pm 0.57$ & 89.75 & 1.79 \\
\hline & IV & 0 & $20.75 \pm 0.50$ & $15.25 \pm 1.25$ & $9.75 \pm 2.62$ & $5.00 \pm 0.81$ & $3.25 \pm 0.95$ & 54.00 & 1.08 \\
\hline \multirow{4}{*}{$\begin{array}{l}\text { Post- } \\
\text { treatment } \\
\text { with ZnO } \\
\text { NPs }\end{array}$} & 1 & 0 & $80.25 \pm 1.25$ & $66.75 \pm 1.70$ & $57.50 \pm 0.80$ & $52.00 \pm 0.81$ & $45.25 \pm 6.25$ & 301.75 & 6.03 \\
\hline & II & 0 & $53.00 \pm 2.16$ & $47.25 \pm 1.89$ & $40.5 \pm 1.29$ & $32.75 \pm 1.70$ & $24.25 \pm 1.70$ & 197.75 & 3.95 \\
\hline & III & 0 & $38.00 \pm 1.41$ & $31.75 \pm 1.70$ & $28.00 \pm 0.81$ & $21.25 \pm 1.25$ & $14.5 \pm 1.29$ & 133.50 & 2.67 \\
\hline & IV & 0 & $28.75 \pm 1.70$ & $20.00 \pm 0.81$ & $14.25 \pm 1.25$ & $12.00 \pm 0.81$ & $8.75 \pm 0.95$ & 83.75 & 8.37 \\
\hline
\end{tabular}

Predation rates are means \pm SD of four replicates (1 G. affinis fish vs. 100 mosquitoes per replication)

No predation in control (i.e. clean water without G. affinis fish)

Within each column, means followed by the same letter are not significantly different $(P<0.05)$

Table 5. Zone of inhibition ( $\mathrm{mm}$ ) by Lawsonia inermis mediated ZnO NPs against bacteria and fungi.

\begin{tabular}{|lll|}
\hline Target & \multicolumn{2}{c|}{ Zone of inhibition $(\mathrm{mm})$} \\
\cline { 3 - 3 } & Zno NPs $(\mu \mathrm{L})$ & Standard \\
\cline { 3 - 3 } Bacteria & & Tetracyclin \\
\hline E. coli & $13.3 \pm 0.5$ & $14.4 \pm 0.4$ \\
\hline Bacillus subtilus & $08.4 \pm 0.4$ & $10.2 \pm 0.2$ \\
\hline Fungi & & Fucanazole \\
\hline Alternaria alternate & $11.5 \pm 0.2$ & $13.1 \pm 0.2$ \\
\hline Aspergillus flavus & $07.8 \pm 0.4$ & $08.1 \pm 0.1$ \\
\hline
\end{tabular}

\section{Figures}




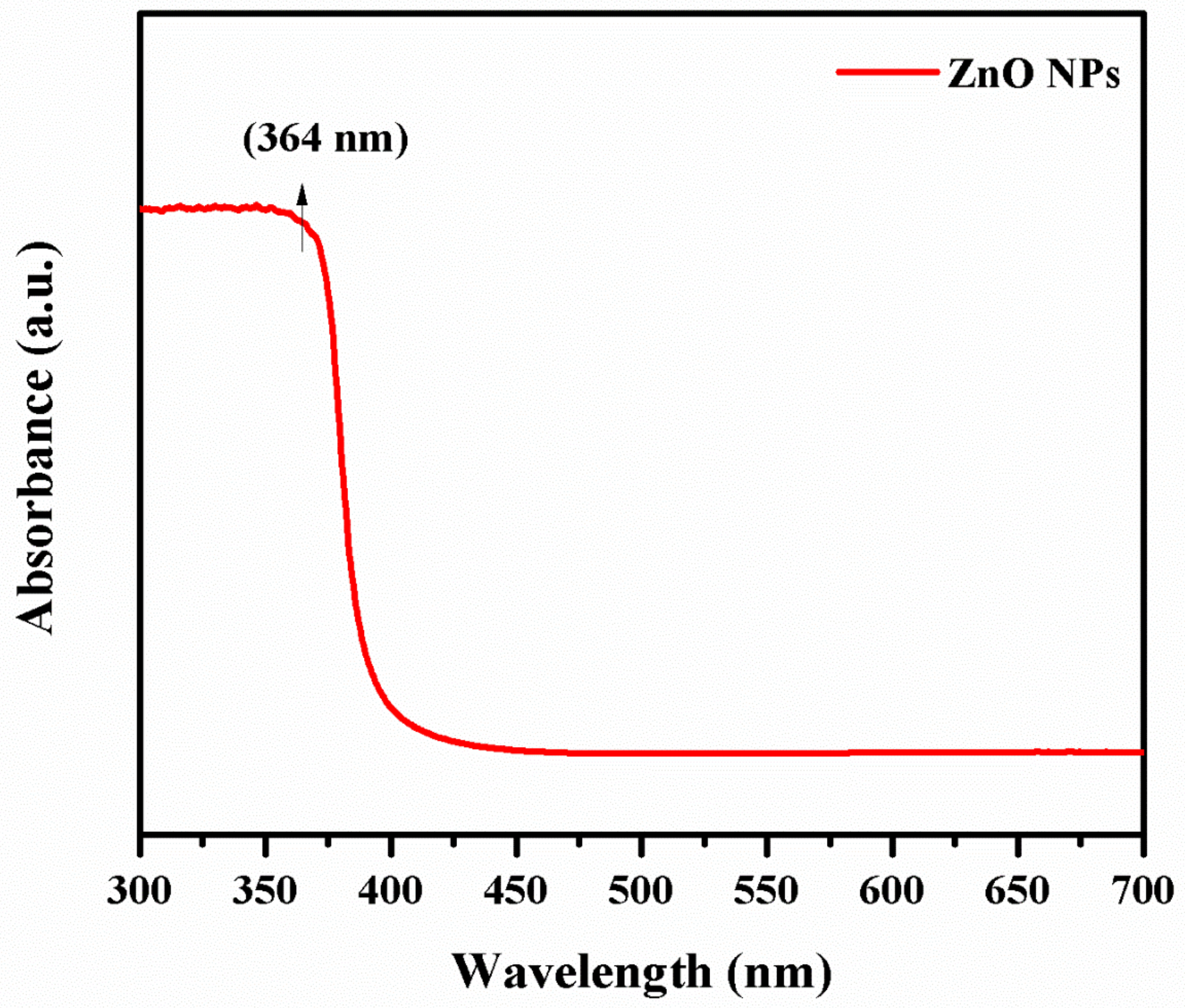

Figure 1

UV-vis-DRS analysis of synthesized ZnO NPs. 
(A)

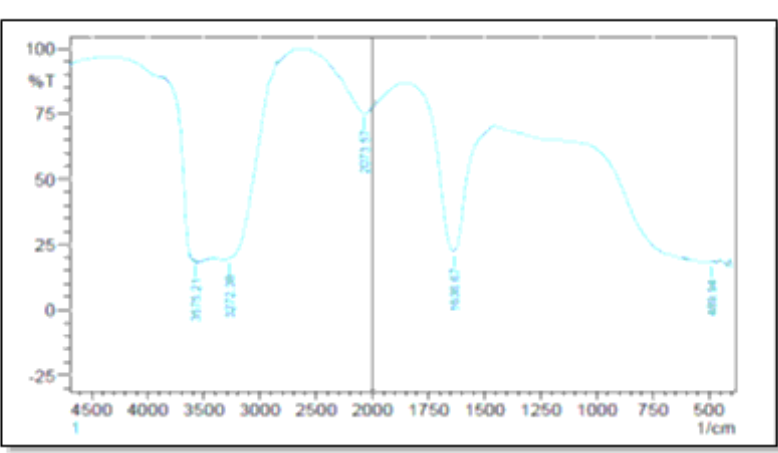

(B)

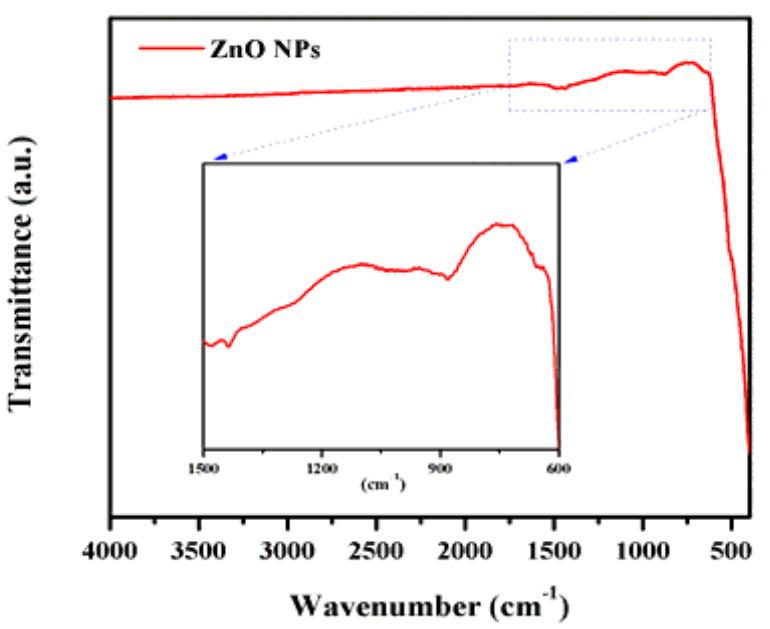

\section{Figure 2}

FTIR spectrum; (A) Lawsonia inermis leaf extract, and (B) synthesized ZnO NPs. 


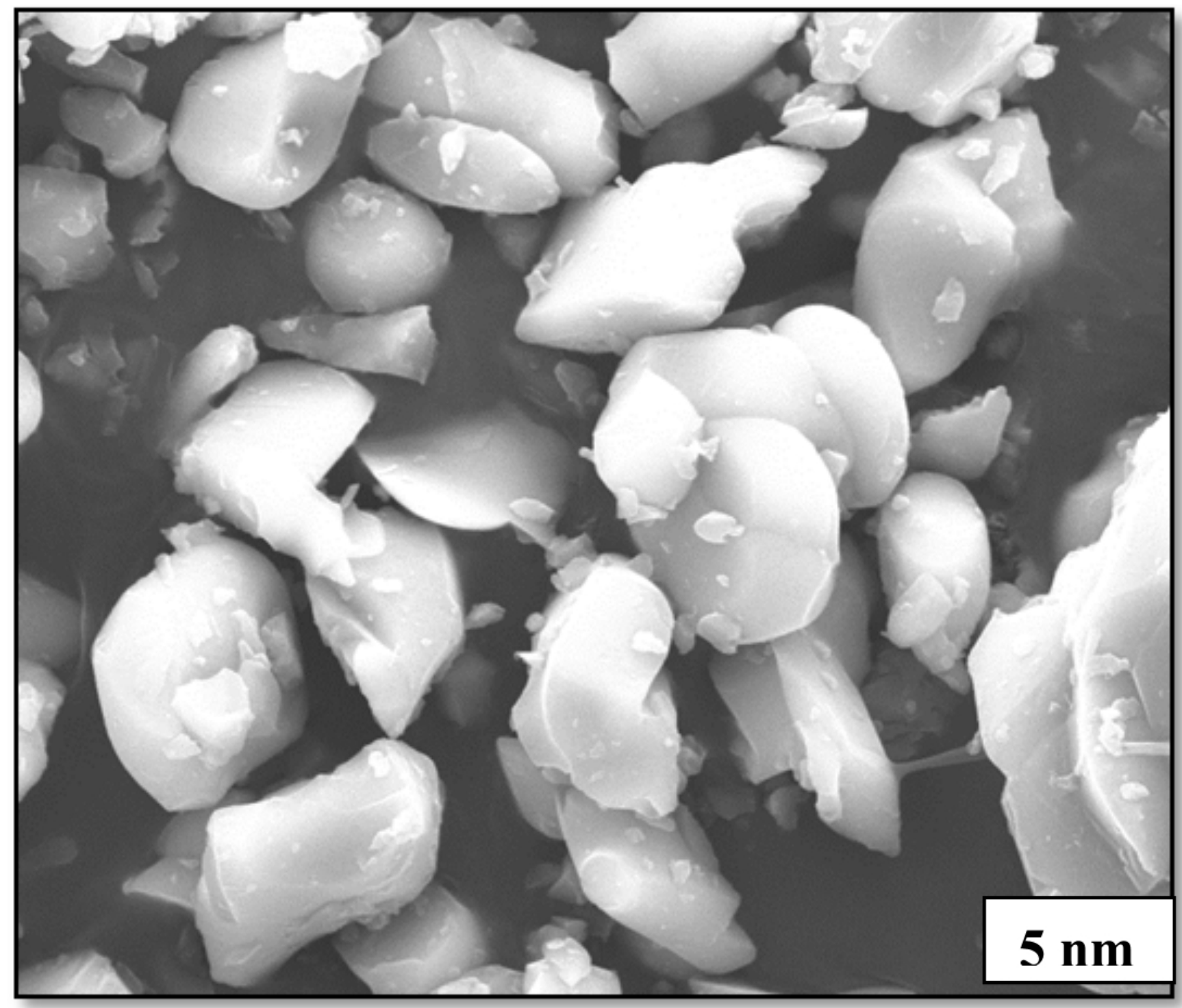

Figure 3

SEM images of synthesized ZnO NPs. 


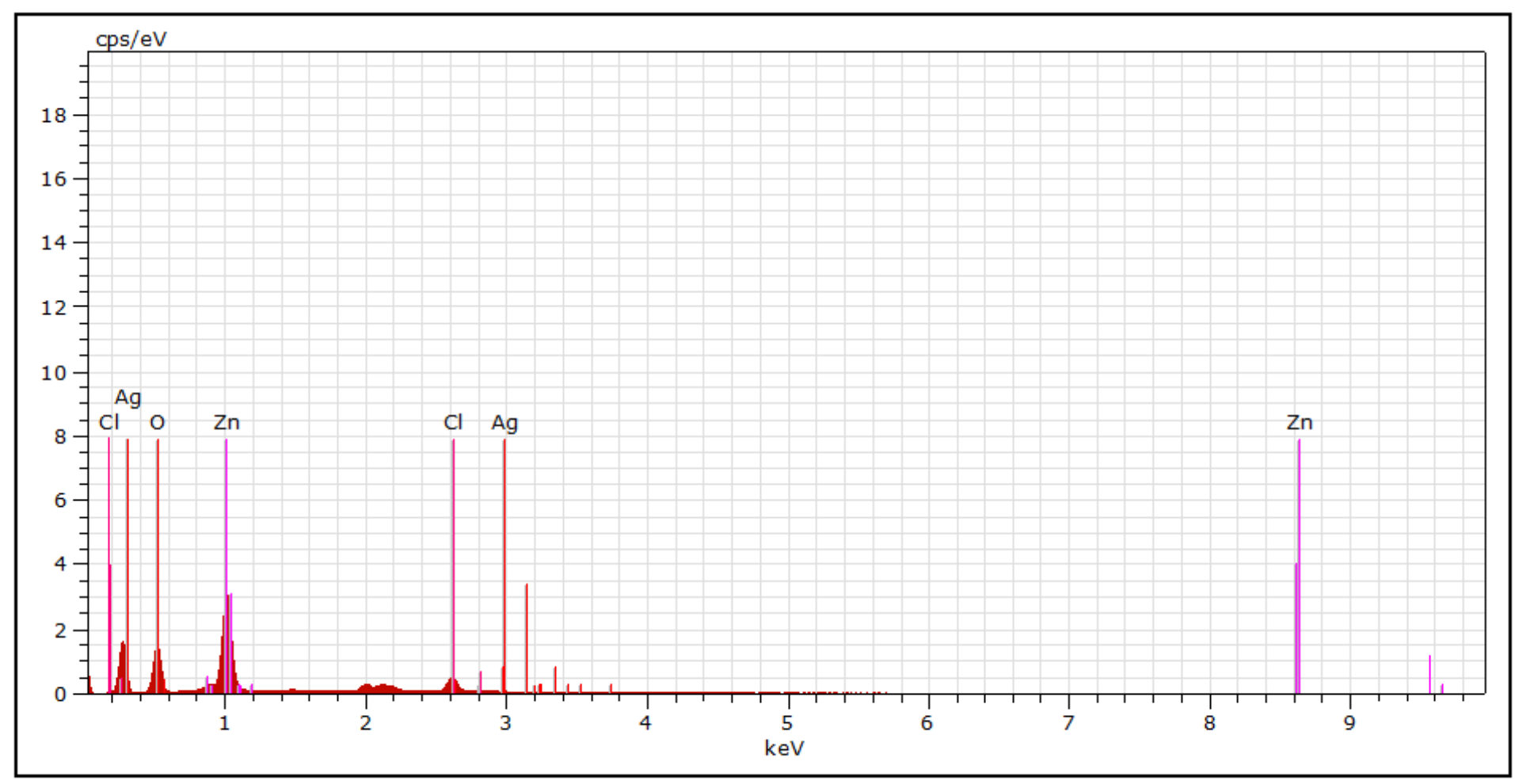

Figure 4

EDX analysis of synthesized ZnO NPs. 


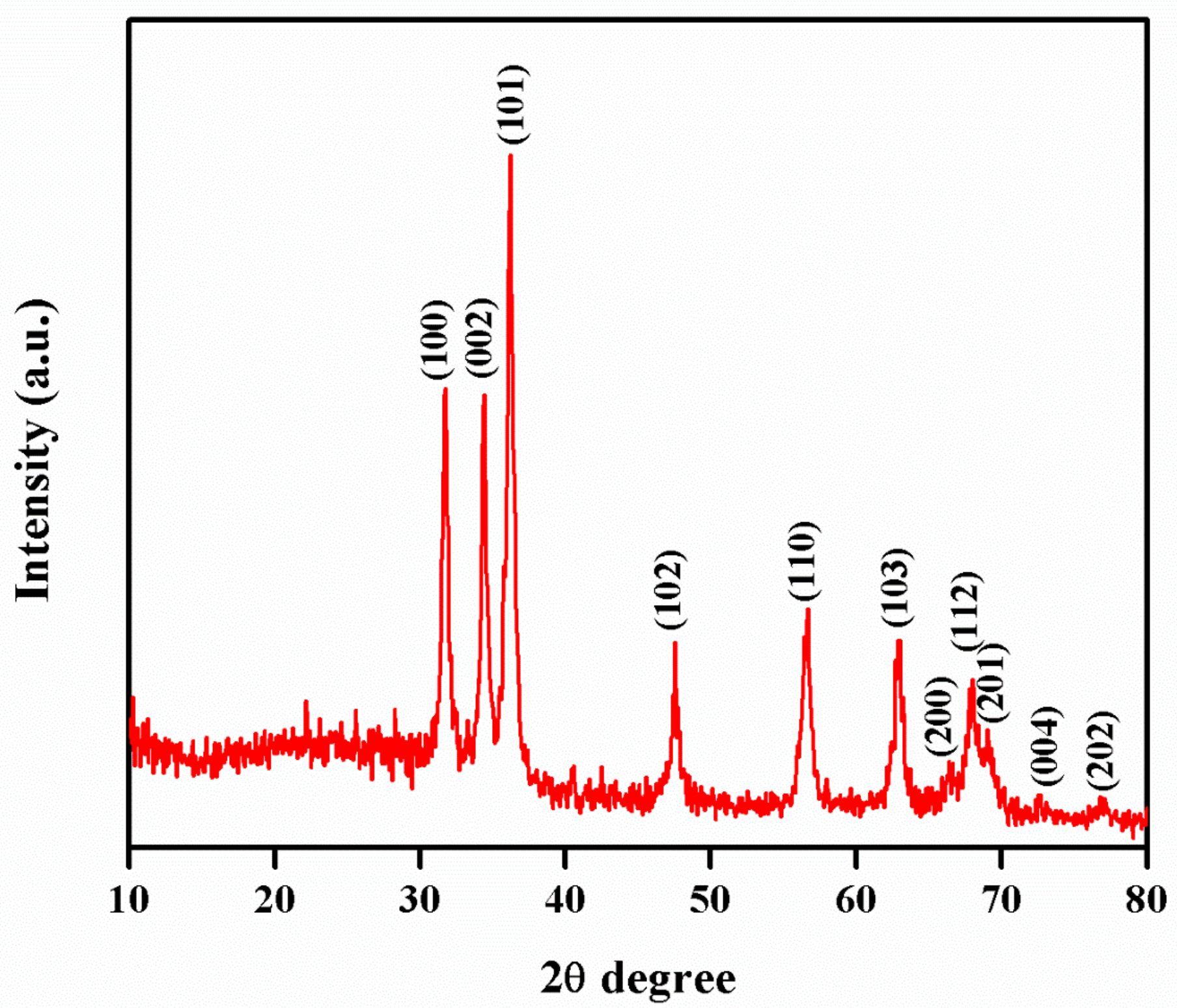

Figure 5

XRD analysis of synthesized ZnO NPs. 

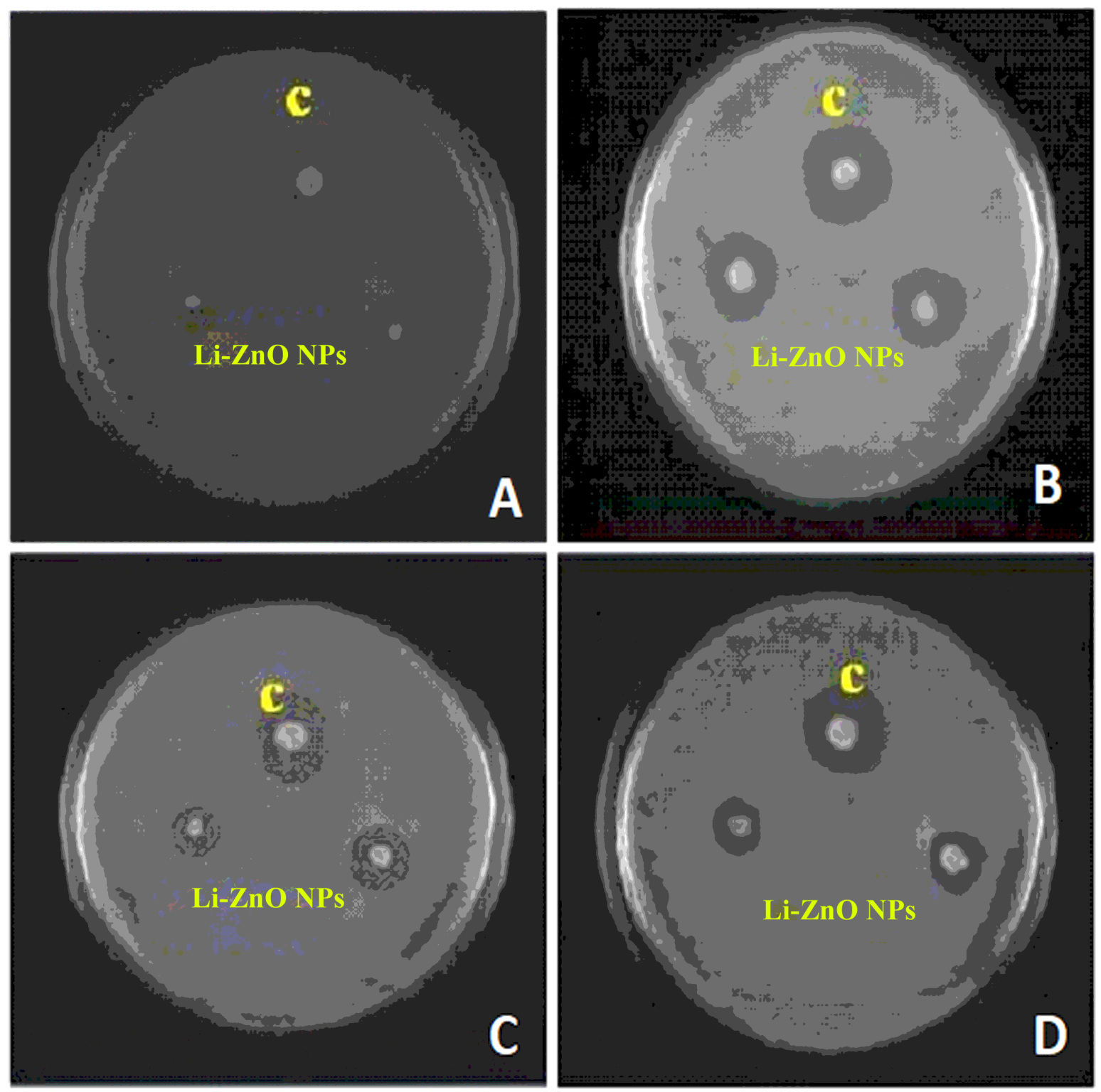

\section{Figure 6}

Inhibitory zone of ZnO NPs against pathogenic bacteria and fungi. A - Escherichia coli, B - Bacillus subtilis, C - Alternaria alternate, D Aspergillus flavus; Standard: tetracycline for bacteria and fluconazole for fungi. 


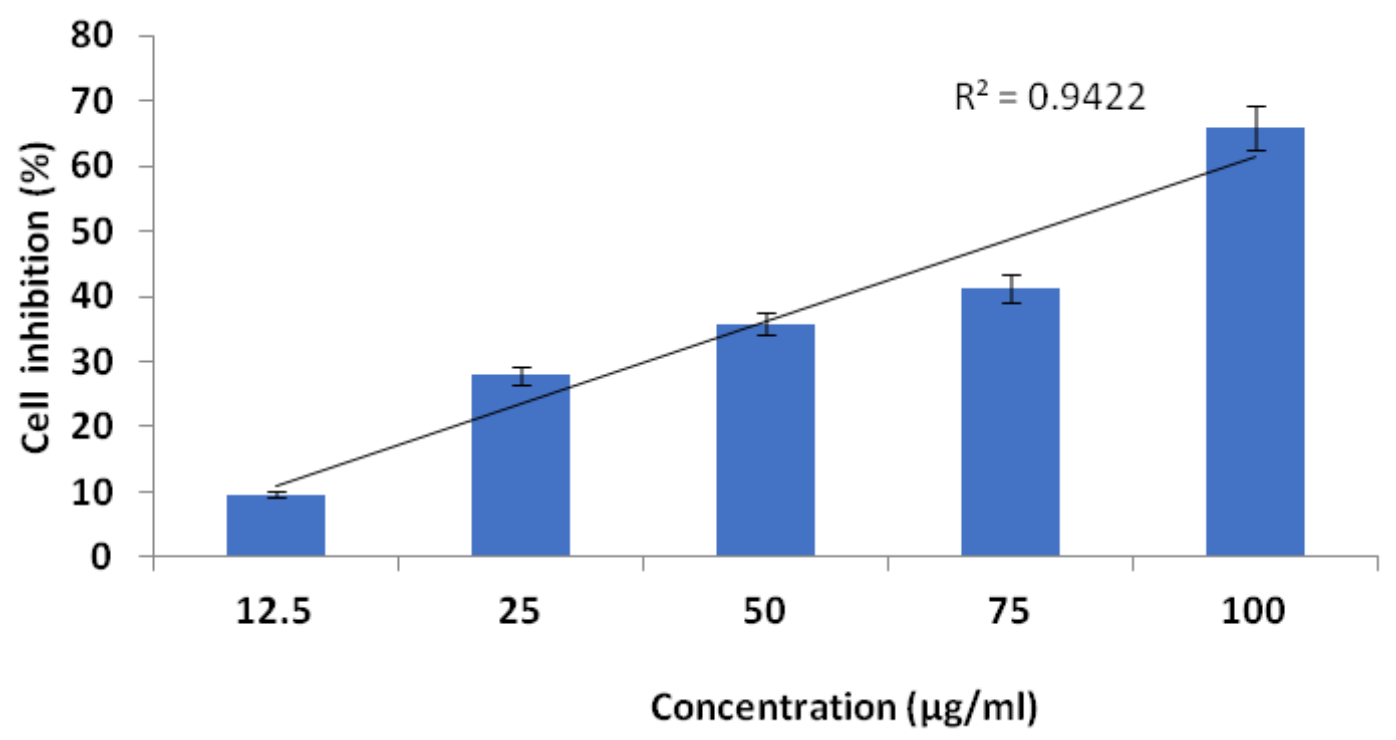

Figure 7

Cytotoxicity of Hep-G2 cancer cell lines mediated by synthesized ZnO NPs: cell growth inhibition (\%); above each column, different letters indicate significant differences among treatments (ANOVA, Tukey's HSD test, $\mathrm{P}<0.05$ )

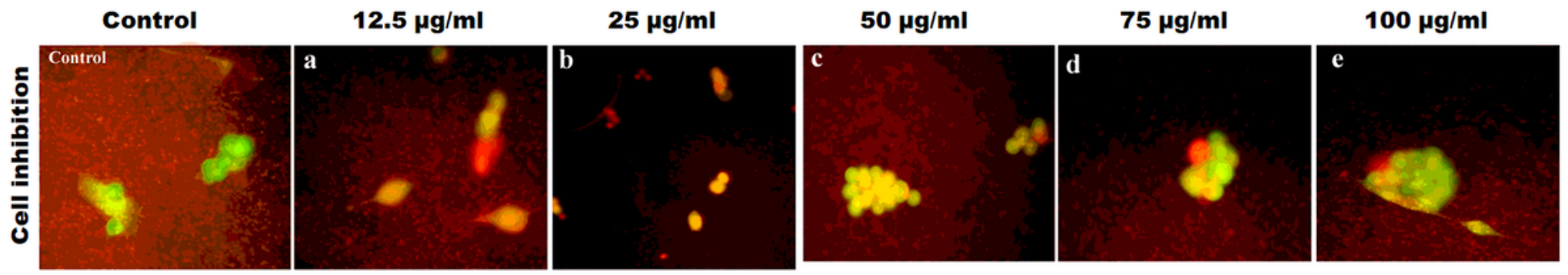

Figure 8

Cell growth inhibition of Hep-G2 cell lines treated with synthesized ZnO NPs.

\section{Supplementary Files}

This is a list of supplementary files associated with this preprint. Click to download.

- Graphicalabstract18Nov201.jpg 